\title{
PENGARUH TEMPERATUR RENDAH PADA SIFAT BENDING DARI PIPA KOMPOSIT EPOXY DENGAN PENGUATAN SERAT JUTE
}

\author{
Ida Ayu N. Pramadyanti ${ }^{1}$, I Ketut Adi Atmika ${ }^{1}$, dan I.D.G. Ary Subagia ${ }^{1 *}$ \\ ${ }^{1}$ Program Studi Teknik Mesin Universitas Udayana, Kampus Bukit Jimbaran Badung (80361) Bali \\ *arsubmt@unud.ac.id
}

Received 12-05-2021, Revised 16-08-2021, Accepted 21-08-2021, Published 1-10-2021

\section{ABSTRACT}

The experiment about the bending behavior of pipe composite based under the lowtemperature treatment was carried out. As for the background of this research is that composite material become a suitable design with user need and it has behavior to substitute metal in engineering products. The research aims to investigate the effect of low temperature against to bending strength behavior of pipe from composite epoxy with jute fiber reinforcement. The low-temperature treatment was applied through an immersion process in dry ice as long as 60 minutes to produces a temperature of $-33^{\circ} \mathrm{C}$. The pipe composite was manufactured in lamination three layers of jute fabric using the vacuum injection molding process (VRTM). Then, the strength of the composite pipe was tested on the three-point bending method according to the ASTM D 790 standard. The testing results show that composite pipe with low-temperature treatment has a flexural strength average of about 76.559 MPa. Meanwhile, the compo-site pipe without treatment shows the strength of flexural average of about 52.435 MPa. They have the strength of flexural inclination is an average of $68 \%$. In addition, the failures of composite in three-point bending test shows a shrank mode on the compression side and flat tearing at tension side due to the material becomes brittle. The conclusion that lowtemperature treatment has an effective influence on the pipe composite mechanical properties.

Keywords: bending test, jute fiber, low temperature, pipe composite, vartm.

\section{ABSTRAK}

Percobaan tentang perilaku lentur komposit pipa dengan perlakuan suhu rendah telah dilakukan. Adapun latar belakang penelitian ini adalah bahwa bahan komposit menjadi desain yang cocok dengan kebutuhan pengguna dan memiliki perilaku untuk mengganti logam dalam produk teknik. Penelitian ini bertujuan untuk menyelidiki efek suhu rendah terhadap perilaku kekuatan lentur pipa dari komposit epoksi dengan penguatan serat jute. Perlakuan suhu rendah diterapkan melalui proses pencelupan dalam es kering selama 60 menit untuk menghasilkan suhu $-33^{\circ} \mathrm{C}$. Komposit pipa diproduksi dalam laminasi tiga lapisan serat jute menggunakan proses pencetakan injeksi vakum (VRTM). Kemudian, kekuatan pipa komposit diuji pada metode three-point bending sesuai standar ASTM D 790. Hasil pengujian menunjukkan bahwa pipa komposit dengan perawatan suhu rendah memiliki kekuatan lentur rata-rata sekitar 76,559 MPa. Sementara itu, pipa komposit tanpa perawatan menunjukkan kekuatan rata-rata kekuatan lentur sekitar 52,435 MPa. Mereka memiliki kecenderungan kekuatan lentur rata-rata $68 \%$. Selain itu, kegagalan komposit dalam uji lentur tiga titik menunjukkan mode menyusut pada sisi kompresi dan robek datar di sisi ketegangan karena bahan menjadi rapuh. Kesimpulan bahwa perawatan suhu rendah telah efektif mempengaruhi sifat mekanik komposit pipa. mengkerut.

Kata kunci: pipa komposit, serat jute, temperatur rendah, uji bending, vartm. 


\section{PENDAHULUAN}

Transportasi zat cair (fluida) sangat tergantung pada pipa. Pipa berbahan logam masih mendominasi dalam transportasi fluida. Akan tetapi dalam dominasinya, pipa logam mulai banyak dikurangi penggunaannya disebabkan oleh sifat korosif yang tinggi, kerapatan tinggi, sulit dalam instalasi. Sekarang ini, pipa dengan bahan dasar plastik seperti polyvinyl chloride (PVC) dan polyethylene (PE) telah mengungguli dominasi pipa berbahan dasar logam ${ }^{[1,2]}$. Keunggulan dari pipa plastik dan turunannya adalah ringan, mudah dalam instalasi, dan tahan korosi, serta non-degradable. Akan tetapi, pipa plastik tidak tahan temperature tinggi maupun rendah dan mudah pecah karena penekanan (kompressi) ${ }^{[3]}$.

Berdasarkan permasalahan tersebut, pemanfaatan bahan dasar komposit untuk pipa semakin banyak dikembangkan dalam dekade terakhir ${ }^{[4-6]}$. Bahan komposit merupakan salah satu material yang dikembangkan sebagai bahan dasar pembentuk pipa. Komposit adalah bahan yang terdiri dari penguat dan pengikat ${ }^{[7]}$. Secara umum penguat adalah berupa serat organic maupun inorganic ${ }^{[8-10]}$. Sedangkan untuk matrik polimer terbagi menjadi 2, yaitu thermosetting dan thermoplastic ${ }^{[11-13]}$. Sifat dari matrik adalah harus mampu mengikat bahan reinforcement dengan baik agar tidak terjadi fenomena fiber pull out, yaitu serat yang terlepas dari matrik. Tujuan dari pengembangan material komposit saat ini adalah untuk menciptakan material yang ringan, sifat mekanik yang unggul, tahan terhadap korosi dan perlakuan kimia, serta murah. Disamping itu bersifat ramah lingkungan ${ }^{[14]}$. Sesuai dengan karakteristik yang dimiliki oleh material komposit secara umum telah mendorong untuk diaplikasikan sebagai bahan pipa pengganti pipa dari bahan plastik.

Sejalan dengan upaya untuk mengembalikan alam, pemerintah telah mendukung dan menghimbau untuk memanfaatkan bahan alami sebagai bahan penguat dari material komposit. Beberapa upaya penelitian terkait sifat mekanik dan phisik dari bahan komposit telah dilakukan. Pickering et $a l^{[15]}$ menganalisa terehadap kemungkinan sifat mekanik dari bahan alami sebagai bahan dasar material komposit. Terhadap sifat kimia dari bahan komposit dipelajari secara intensif oleh Naidu et $a l^{[11]}$. Kemudian terhadap daya serap air oleh bahan komposit diteliti oleh Sature et al ${ }^{[16]}$. Aplikasi bahan komposit pada pipa dipelajari oleh Amid et $a l^{[6]}$ yang mengkaji sifat mekanik dari pipa komposit yang dibuat dengan kain tenun melingkar dalam struktur kontinu berbentuk jaring orthogonal dengan bahan poliester. Selanjutnya pipa komposit dengan orientasi serat telah dikaji oleh Dihia et $a l^{[17]}$. Sifat dari komposit dengan serat alami flax setelah kompressi kejut (impact compression) diselidiki oleh Habibi et $a l^{[18]}$. Adapun hasil yang didapat adalah dampak energi thresh-old telah menunjukkan efek signifikan terhadap terbentuknya faktor-faktor seperti kekuatan sisa, pada tiap kegagalan komposit karena pemuatan kompresi. Kajian kajian dari sifat mekanik dan phisik dari pipa dengan bahan komposit juga dilakukan oleh beberapa peneliti ${ }^{[4,9,19,20,22-24]}$. Secara khusus pada pipa komposit terhadap pembebanan bending dilakukan oleh ${ }^{[2,25]}$

Sejalan dengan penggunaan serat alam sebagai penguat serat jute adalah serat yang paling banyak diaplikasikan. Serat jute ${ }^{[26]}$ merupakan salah satu bahan alami dari tumbuhan dengan sifat dan karakteristik yang paling baik di antara serat alami lainnya. Pemanfaatan jute sebagai penguat komposit sudah banyak dilakukan dan diteliti ${ }^{[7,27,28]}$, akan tetapi belum banyak diaplikasikan pada pipa untuk temperatur rendah.

Dari state of the art, suatu yang menarik untuk dianalisa dalam penelitian ini adalah sifat pipa komposit resin epoksi berbasis penguatan serat jute dengan perlakuan temperatur 
rendah yaitu $-33^{\circ} \mathrm{C}$ terhadap pembebanan bending. Pembebanan bending pada penelitian ini diaplikasikan metode three-point bending procedure menurut standar ASTM D 790. Tujuan penelitian untuk menginvestigasi pengaruh perlakuan temperatur rendah pada bahan komposit yang diaplikasikan sebagai bahan pipa. Laminasi anyaman serat dilakukan untuk membentuk pipa yang masing-masing variasi diujikan sebanyak lima kali pengulangan. Hasil pengujian ditampilkan dalam bentuk grafik, dan patahan ditampilkan secara jelas dengan resolusi yang tinggi.

\section{METODE}

Bahan komposit untuk pipa dipergunakan serat jute sebagai penguat dan epoxy resin EPR 147 Bespinol A dengan Hardener type Cyclonliphatic Amine EPH 555 sebagai matriks. Karakteristik dari kedua bahan utama komposit ditunjukkan seperti pada Tabel 1 dan Tabel 2. Bahan pendukung untuk pembuatan dari komposit pipa adalah dry ice (ditunjukkan pada Gambar 2) yang dipergunakan untuk pengkondisian temperatur dari benda uji (pipa komposit).
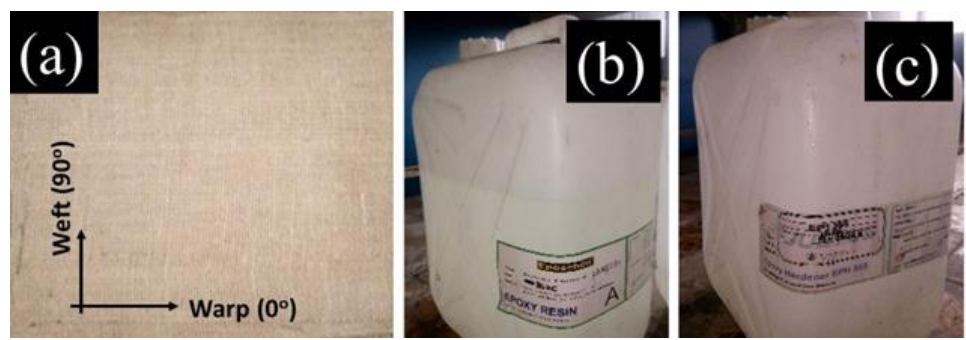

Gambar 1. (a) Serat Anyaman Jute, (b) Resin epoksi, (c) Hardener

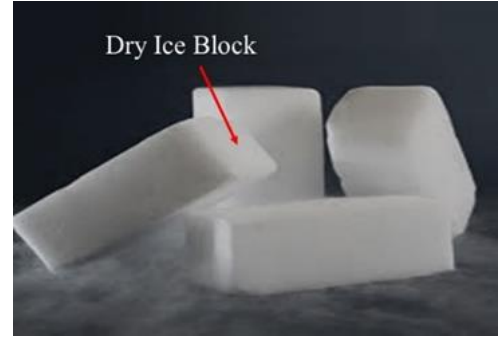

Gambar 2. Dry Ice block

Tabel 1. Sifat mekanis serat jute tanpa perlakuan ${ }^{[9]}$

\begin{tabular}{lc}
\hline \multicolumn{1}{c}{ Category/Unit } & Standard \\
\hline Diameter Serat $(\mu \mathrm{m})$ & 26 \\
Panjang Serat $(\mathrm{mm})$ & $1-5$ \\
Kehalusan serat (denier) & $3-7$ \\
Berat Jenis $\left(\mathrm{g} / \mathrm{cm}^{3}\right)$ & $1,5-1,6$ \\
Mulur $(\%)$ & 1,7 \\
Fracture Load $(\mathrm{N})$ & 0,467 \\
Tensile Strength $(\mathrm{MPa})$ & 1.316 \\
Fracture Strain $(\%)$ & 0,025 \\
Modulus Young $(\mathrm{Gpa})$ & 91,9 \\
\hline
\end{tabular}

Tabel 2. Karakteristik epoxy resin EPR-174

\begin{tabular}{lc}
\hline \multicolumn{1}{c}{ Category/Unit } & Standard \\
\hline Density at $25^{\circ} \mathrm{C}\left(\mathrm{g} / \mathrm{cm}^{3}\right)$ & $1,16 \pm 0,02$ \\
Hardener Type & Cyclonliphatic Amine $(\mathrm{EPH}-555)$ \\
Epoxy Resin Type & Bisphenol A-Epichlorohydrin \\
Tensile Strength $(\mathrm{MPa})$ & 63,7 \\
Compressive Strength $(\mathrm{MPa})$ & 88,2 \\
Flexural Strength $(\mathrm{MPa})$ & 81,3 \\
Viscocity at $25^{\circ} \mathrm{C}$ & $13.000 \pm 2.000$ \\
\hline
\end{tabular}


Gambar 3a menunjukkan tahapan pembuatan pipa komposit melalui proses cetakan injeksi. Sistem yang dipergunakan pada proses ini adalah Vacuum Resin Transfer molding (VRTM). Adapun tahapan dari pembuatan pipa komposit adalah dimulai dari persiapan dasar cetakan yaitu pipa PVC dengan diameter 1 inch. Pada dasar cetakan (mandrel) dilapisan dengan lapisan lilin (wax) untuk mempermudah melepas hasil cetakan. Tahap berikutnya adalah proses laminasi serat anyaman goni (jute) sebanyak tiga lapisan. Kemudian, setelah laminasi serat dilakukan pelapisan dengan menggunakan release cotton dan dilanjutkan dengan melapisi lamisasi dengan breather net. Selanjutnya dilapisi dengan plastic bag seperti ditunjukkan pada Gambar 3. Tahap selanjutnya adalah pencampuran matrik yaitu epoxy resin EPR 147 dan hardener EPH 555 dengan perbandingan 2:1. Tahap selanjutnya adalah proses injeksi yang lakukan dengan tekanan vakum adalah (-0.8Pa) selama kurang lebih 40 menit. Tahap akhir adalah proses pengeringan hasil injeksi selama 24 jam. Hasil dari cetak ditunjukkan pada Gambar 3b.

Perlakuan temperatur rendah untuk pipa komposit dilakukan dengan merendam benda kerja pada dry ice selama 60 menit, hingga temperatur mencapai $-33^{\circ} \mathrm{C}$. Proses perendaman dari benda kerja ditunjukkan pada Gambar 4.

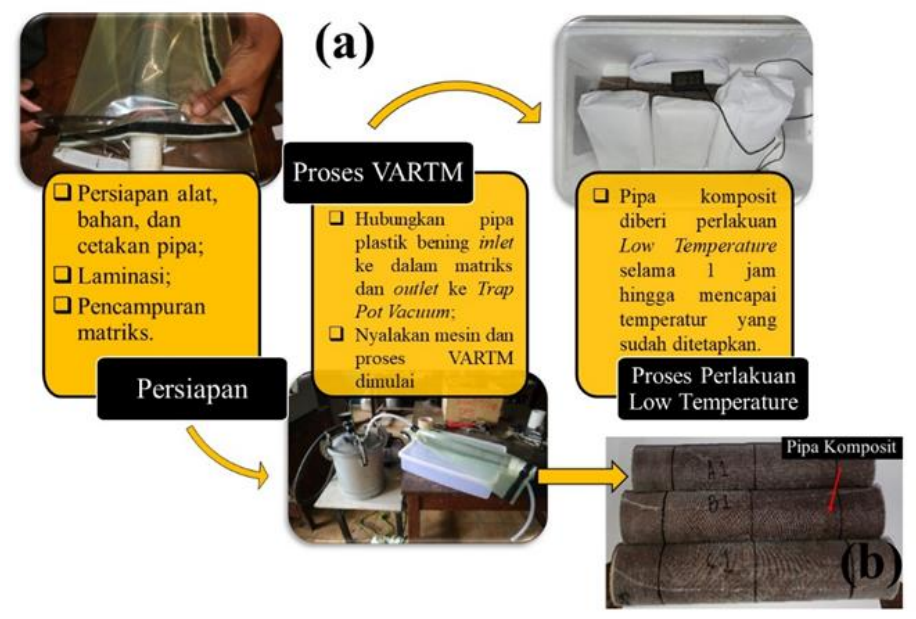

Gambar 3. (a) Proses manufaktur pipa komposit, (b) benda kerja pia komposit

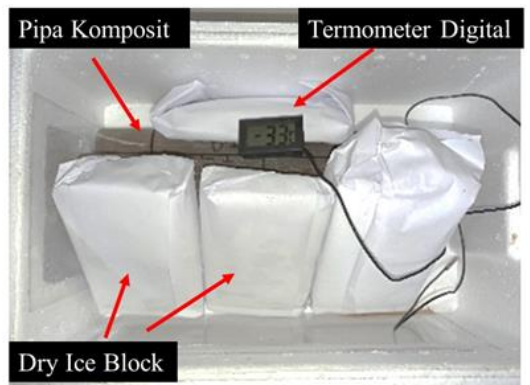

Gambar 4. Proses perlakuan temperature rendah dari pipa komposit pada dry ice 

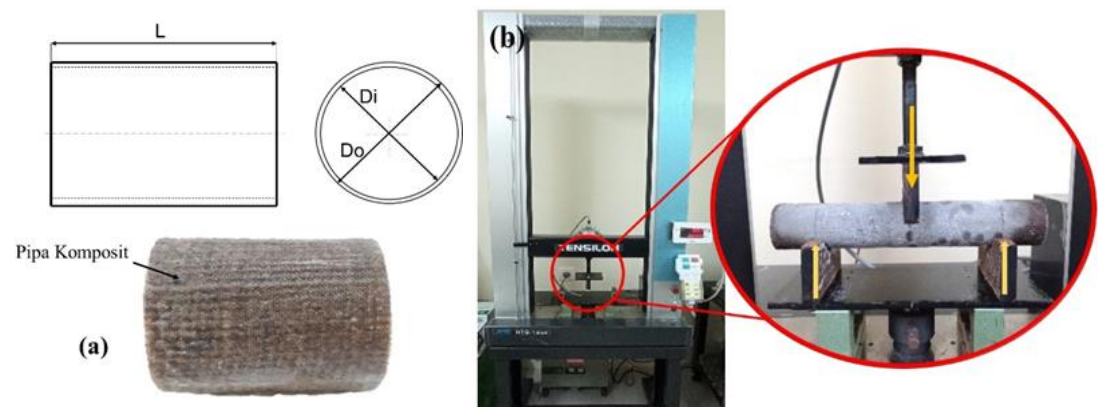

Gambar 5 a) Geometri benda uji; b). Uji three-point bending pada UTM

Pengujian bending dilaksanakan menggunakan Universal Tension Machine (UTM). Pada pengujian three-point bending, panjang specimen adalah $300 \mathrm{~mm}$ dengan jarak tumpuan adalah 2 x 10\% panjang benda uji. Pengujian three-point bending ditunjukkan seperti pada Gambar 5b. Pengujian three-point bending didasarkan pada standar ASTM D 790 dengan load cell 5kN dan kecepatan cross head speed adalah $200 \mathrm{~mm} / \mathrm{s}$. Pengujian dilakukan sebanyak 5 kali pengulangan. Sebelum pengujian, ketebalan dan lebar sampel komposit diukur dengan micrometer dengan akurasi $\pm 1 \%$. Pengolahan data uji three-point bending ditentukan dengan persamaan sebagai berikut:

$$
\begin{aligned}
& M=\frac{(F \cdot L)}{4} \\
& Z=\frac{\pi\left(D_{0}^{3}-D_{1}^{3}\right)}{32} \\
& \text { Bending Stress }=\frac{M}{Z}=\frac{(8 F L)}{\pi\left(D_{0}^{3}-D_{i}^{3}\right)} \\
& \text { Strain }=\frac{6\left[\left(D_{0}-D_{i}\right) D \cdot L\right]}{L^{3}}
\end{aligned}
$$

Dimana; $\mathrm{M}=$ Momen Bending (Nmm), $\mathrm{F}=$ Besar beban $(\mathrm{N}), \mathrm{L}=$ Jarak tumpuan $(\mathrm{mm}), \mathrm{Z}$ $=$ Rectangular section Modulus $\left(\mathrm{mm}^{3}\right), \mathrm{D}_{\mathrm{o}}=$ Diameter luar spesimen $(\mathrm{mm}), \mathrm{D}_{\mathrm{i}}=$ Diameter dalam spesimen $(\mathrm{mm}), \varepsilon=$ Regangan, $\mathrm{DL}=$ Deflection in bending $(\mathrm{mm})$.

Gambar 5a menunjukkan dimensi benda uji yaitu diameter luar $D_{o}=48 \mathrm{~mm}$; diameter dalam $D_{i}=43 \mathrm{~mm}$; panjang $\ell=300 \mathrm{~mm}$; tebal pipa $=D_{o}-D_{i}=(48-43) \mathrm{mm}=5 \mathrm{~mm}$

Kerapatan massa dari material komposit ditentukan dengan persamaan sebagai berikut;

$$
\begin{aligned}
& \rho_{c a}=S_{c t} \cdot \rho_{\text {Kerosene }} \\
& S_{c t}=\frac{\left(w_{0}\right)}{w_{0}+\left(w_{a}-w_{b}\right)}
\end{aligned}
$$

dimana; $\rho_{c a}=$ densitas komposit, $\rho_{\text {kerosene }}=$ kerapatan kerosin $\left(0,81 \mathrm{gr} / \mathrm{cm}^{3}\right), S_{c t}=$ gravitasi spesifik dari komposit, $w_{o}=$ berat awal sampel, $w_{a}=$ berat gelas + kerosin, $w_{b}=$ berat gelas + kerosin + sampel, $w_{\text {Gelas } \text { Ukur }}=284,04$ gram, $w_{\text {Kerosin }}=200$ gram.

Dari hasil perhitungan untuk rata - rata berat benda uji untuk $w_{0}=0.25 \mathrm{grm}, w_{a}=484.5$ gram dan $w_{b}=484.7$ gram maka density dan specific gravitation dari pipa komposit diperoleh nilai grafitasi spesifik komposit sebesar 12.5 gram dan kerapatan massa dari komposit adalah 10.125 gram $/ \mathrm{cm}^{3}$. 


\section{HASIL DAN PEMBAHASAN}

\section{Perpatahan pada perlakuan temperatur rendah}

Patahan dari pipa komposit merupakan kejadian karena adanya pembebanan gaya statis pada material sehingga terjadi pemisahan dari sebuah kesatuan menjadi dua bagian atau lebih. Dalam kata patah pada material secara umum, dikenal adanya patah ulet dan patah getas. Ini didasarkan pada kemampuan material untuk dapat berdeformasi secara plastis. Pada pengujian karena pembebanan tekan (bending) terhadap pipa komposit didapatkan patahan seperti ditunjukkan pada Gambar 6. Pada pembebanan tekan untuk pipa didapatkan dua kondisi pembebanan yaitu tekan (compressi) dan tarik (tensile). Kondisi kompresi adalah dialami pada daerah permukaan yang langsung dikenakan beban. Bentuk kegagalan yang timbul adalah pengkerutan di daerah beban. Sedangkan, disisi bersebrangan menerima beban tarik yang ditunjukkan dengan adanya patah ${ }^{[29,30]}$. Adapun bentuk penampang patahan dari bahan komposit dengan setelah perlakuan adalah adalah datar dan tidak terjadi pull-out dibandingkan dengan patahan tanpa perlakuan. Sedangkan, patahan menyeluruh dari pipa setelah perlakuan, karena sifat getas bahan menimbulkan adanya rambatan retak, sehingga patahan yang terjadi terstruktur mengikuti arah retakan seperti ditunjukkan oleh tanda panah pada Gambar 6 .

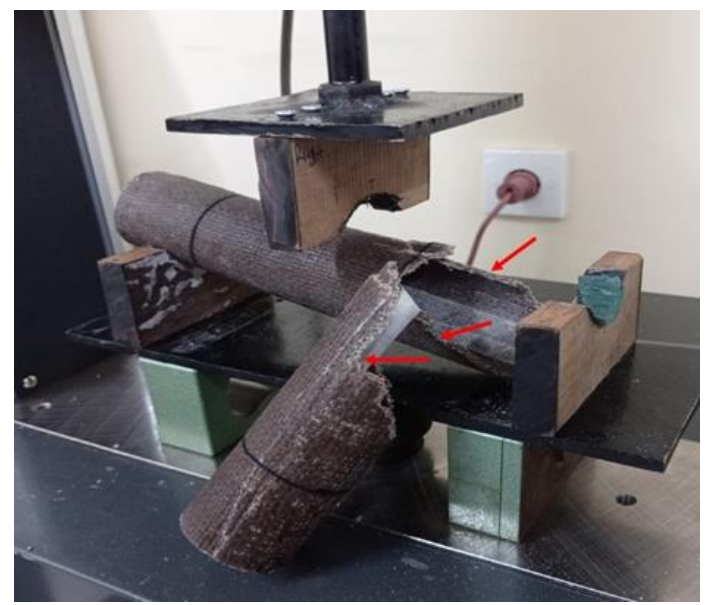

Gambar 6. Patahan pipa komposit

Three-point Bending pada pipa komposit

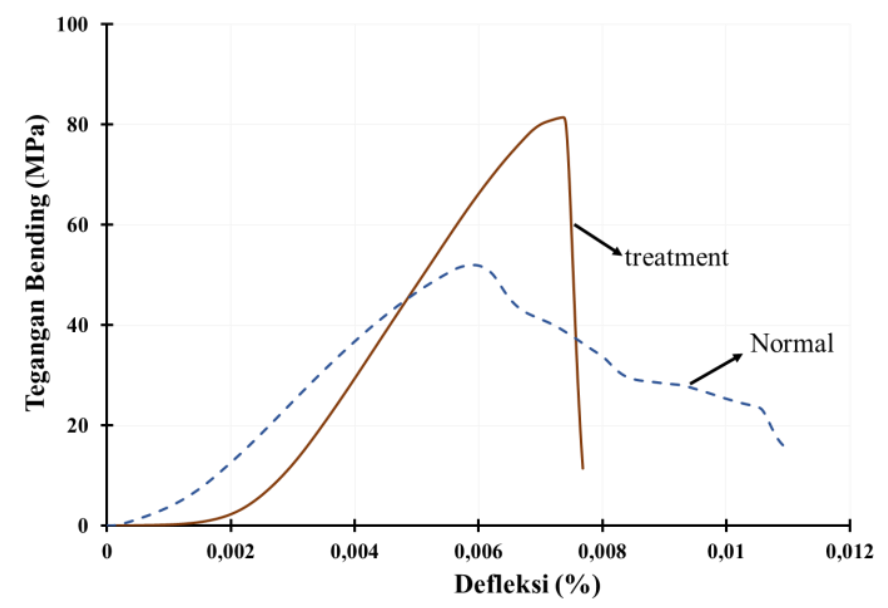

Gambar 7. Grafik tegangan dan defleksi three-point bending 
Gambar 7 menunjukkan hubungan antara tegangan dan defleksi dari material pipa komposit tanpa dan dengan perlakuan temperatur rendah pada pengujian three-point bending di mesin UTM. Dari Gambar 6 tersebut dapat dijelaskan bahwa antara benda uji tanpa dan dengan perlakuan temperatur menggunakan dry ice selama 60 menit terdapat perbedaan pencapaian sifat mekanis. Pada benda kerja tanpa perlakuan (normal) terjadi kenaikan tegangan secara linier hingga mencapai tegangan ultimate kompressi sebesar $52.435 \mathrm{MPa}$. Pencapaian dari benda kerja normal hingga patah pada bagian tekan dari pipa adalah dimulai dari regangan $0.6 \%$ hingga berlajut patah pada sisi tarik dari pipa adalah $0.01 \%$. Pencapian ini berbeda dengan pipa komposit yang dikenakan perlakuan (treatment) menggunakan dry ices Dari grafik terlihat terjadi kenaikan tegangan kompressi sebesar 76,56 MPa jauh lebih tinggi dari tegangan kompressi yang dicapai oleh pipa komposit normal. Akan tetapi, karena pengaruh dari perlakuan temperatur memperpendek regangan yang dicapai benda kerja. Hal ini berarti bahwa material dengan perlakuan temperatur rendah menjadikan material bersifat getas (brittle). Regangan yang dicapai oleh material dengan treatmen adalah sebesar $0.008 \%$. Hal ini juga dibuktikan dengan bentuk patahan benda kerja seperti ditunjukkan pada Gambar 6. Dari hasil yang dicapai juga disampaikan senada dalam penelitian yang dilakukan oleh ${ }^{[29-32]}$, dimana dijelaskan bahwa temperatur besar pengaruhnya terhadap sifat bending dari material komposit baik berbahan dasar serat organic maupun serat inorganic ${ }^{[33]}$. Keunggulan dari treatment pada low temperature juga meningkatkan interfacial bending strength sebesar 31\%. Hasil pengujian dari masing - masing benda uji adalah ditunjukkan seperti pada Tabel 3.

Tabel 3. Data Uji Bending

\begin{tabular}{lccc}
\hline \multirow{2}{*}{ Benda uji } & $\begin{array}{c}\text { Tegangan } \\
(\mathrm{MPa})\end{array}$ & $\begin{array}{c}\text { Regangan } \\
(\%)\end{array}$ & $\begin{array}{c}\text { Modulus } \\
(\mathrm{GPa})\end{array}$ \\
\hline Normal & 52,435 & 0,008 & 5,981 \\
Low Temperature & 76,559 & 0,007 & 10,325 \\
\hline
\end{tabular}

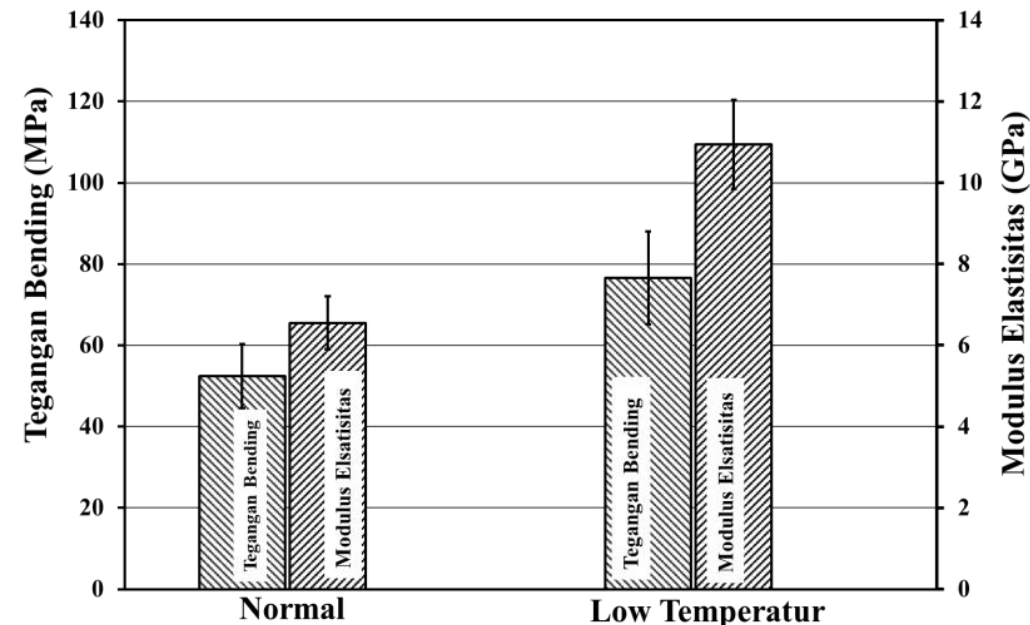

Gambar 8. Grafik tengangan dan modulus elastisitas bending pipa komposit normal dan temperatur rendah

Gambar 8 menampilkan hubungan sifat pembebanan three-point bending pada pipa komposit tanpa dan dengan perlakuan temperatur rendah. Hasil perhitungan untuk pipa komposit tanpa dan dengan perlakuan ditunjukkan seperti pada Tabel 3. Dimana diperoleh tegangan untuk pipa komposit tanpa perlakuan temperatur rendah adalah sebesar 52.435 $\mathrm{MPa}$, dengan modulus elastisitas sebesar $5.981 \mathrm{GPa}$. Kemudian pipa komposit yang diberikan perlakuan temperatur rendah memiliki sifat tegangan bending sebesar 76.559 $\mathrm{MPa}$, dengan modulus elastisitas $10.325 \mathrm{GPa}$. Berdasarkan teori dan hasil - hasil penelitian sebelumnya, diperoleh bahwa pada temperatur rendah, tegangan mengalami 
peningkatan, Perlakukan ini disebabkan oleh beban yang diberikan secara penuh diterima oleh serat penguat. Hal ini disebabkan karena matrik umumnya menjadi sangat getas dan patah pada beban rendah. Hasil pengujian tersebut di atas adalah memiliki trend serupa dengan hasil penelitian yang telah dilakukan peneliti sebelumnya ${ }^{\text {[2231,34-36] [22,31,34-36] }}$

\section{KESIMPULAN}

Pada penelitian ini benda uji berupa pipa dengan bahan komposit telah dibuat menggunakan metode vakum resin tranfer molding (VRTM). Komposit di buat menggunakan bahan penguat anyaman serat jute dengan jumlah lapisan sebanyak 3 lapis. Pada benda uji diberikan perlakuan temperatur rendah hingga suhu $-33^{\circ} \mathrm{C}$ yang dikondisikan dengan menggunakan es kering selama 60 menit, dan diuji pada pembebanan bending arah lateral hingga patah pada Universal Tension Machine, dengan pengulangan sebayak 5 kali untuk masing-masing benda uji. Sebagai acuan dalam pengujian digunakan standar ASTM D 970. Hasil dari pengujian didapatkan bahwa pada tegangan bending antara pipa berbahan komposit jute/resin epoksi naik sebesar $0.68 \%$ dibanding dengan pipa komposit tanpa perlakuan (normal). Selain itu, defleksi yang dihasilkan menjadi sangat rendah karena suhu rendah telah merubah sifat fleksibilitas bahan menjadi sangat kaku (patah getas). Kemudian dari hasil tersebut diperoleh bahwa Modulus Young's meningkat sebesar $0.5 \%$. Dapat disimpulkan bahwa perlakuan temperatur meningkatkan ketegangan (stress) namun bahan komposit menjadi sangat getas dan sangat berbahaya karena dapat patah secara mendadak.

\section{UCAPAN TERIMAKASIH}

Penulis mengucapkan terima kasih kepada Tim Advance Material dan Lab Metalurgi di Program Studi Teknik Mesin, Fakultas Teknik, Universitas Udayana yang telah memberikan dukungan untuk mewujudkan paper ini.

\section{DAFTAR PUSTAKA}

1 Ngafwan dan Effendi, E. 2015. Analisa kekuatan pipa komposit serat batang pisang polyester yang disusun dua lapis serat $25^{\circ} / 25^{\circ}$ terhadap sifat fisis dan mekanis pada temperatur ruang uji $35^{\circ} \mathrm{c}$, $45^{\circ} \mathrm{c}$ dan $55^{\circ} \mathrm{c}$. Simposium Nasional RAPI XIV - 2015 FT UMS, Surakarta, 268-274.

2 Syamsul Hadi, R.N. Akhsanu Takwin, dan Dani, A. 2016. Uji kekuatan tekan dan kekuatan lentur pipa air pvc. Jurnal logic, 16 (1), 7-13.

3 Kumar, A., Sreekala, K., \& Arun, S. 2012. Studies on properties of bio-composites from ecoflex/ramie fabric-mechanical and barrier properties. Journal of Biomaterials and Nanobiotechnology, 03 (3), 396-404.

4 Menshykova, M. \& Guz, I.A. 2014. Stress analysis of layered thick-walled composite pipes subjected to bending loading. International Journal of Mechanical Sciences, 88, 289-299.

5 Pamuk, G. 2014. Development of tubular knitted fabric-reinforced composite pipes. Journal of Industrial Textiles, 45 (5), 944-956.

6 Amid, H., Jeddi, A.a.A., Salehi, M., Dabiryan, H., \& Pejman, R. 2016. Investigation of circular woven composite preforms for composite pipes. Autex Research Journal, 16 (2), 100-108.

7 Guptaa, M.K., Srivastavaa, R.K., \& Bisariaa, H. 2015. Potential of jute fibre reinforced polymer composites: A review. International Journal of Fiber and Textile Research, 5 (3), 30-38. 
8 Shubhra, Q.T.H., Alam, A., \& Quaiyyum, M.A. 2011. Mechanical properties of polypropylene composites. Journal of Thermoplastic Composite Materials, 26 (3), 362-391.

9 Girijappa, T., Mavinkere Rangappa, Y.G., Parameswaranpillai, \& J., Siengchin, S. 2019. Natural fibers as sustainable and renewable resource for development of ecofriendly composites: A comprehensive review. Frontiers in Materials, 6.

10 De Castro, B.D., De Faria, P.E., Vieira, L.M.G., Rubio, C.V.C., Maziero, R., De Matos Rodrigues, P.C., \& Rubio, J.C.C. 2020. Recycled green pe composites reinforced with woven and randomly arranged sisal fibres processed by hot compression moulding. Acta Technologica Agriculturae, 23 (2), 81-86.

11 Naidu, A.L. \& Rao, P.R. 2016. A review on chemical behaviour of natural fiber composites. International Journal of Chemical Sciences, 14 (4), 2223-2238.

12 Nurazzi, M., Khalina, N., Sapuan, A., Laila, S.D., Rahmah, A., \& Hanafee, Z. 2017. A review: Fibres, polymer matrices and composites. Pertanika Journal of Science \& Technology, 25 (4).

13 Sanivada, U.K., Marmol, G., Brito, F.P., dan Fangueiro, R. 2020. Pla composites reinforced with flax and jute fibers-a review of recent trends, processing parameters and mechanical properties. Polymers (Basel), 12 (10).

14 Fidelis, A,M.E., Pereira, T.V.C., Gomes, O.D.F.M., De Andrade Silva, F., \& Filho, T.R.D. 2013. The effect of fiber morphology on the tensile strength of natural fibers. Journal of Materials Research and Technology, 2 (2), 149-157.

15 Pickering, K.L., Efendy, M.G.A., dan Le, T.M. 2016. A review of recent developments in natural fibre composites and their mechanical performance. Composites Part A: Applied Science and Manufacturing, 83, 98-112.

16 Sature, P. \& Mache, A. 2015. Mechanical characterization and water absorption studies on jute/hemp reinforced hybrid composites. American Journal of Materials Science, 5 (3C), 133-139.

17 Dihiaa, S.L., Rachidb, B., \& Boualem, S. 2018. Influence of fiber orientation on the behavior of composite pipes subject to internal pressures. Nature \& Technology Journal, Vol.A: Fundamental and Engineering Sciences, 18, 77-82.

18 Habibi, M., Selmi, S., Laperrière, L., Mahi, H., \& Kelouwani, S. 2019. Post-impact compression behavior of natural flax fiber composites. Journal of Natural Fibers, 17 (11), 1683-1691.

19 Eyvazian, A., Mozafari, H., \& Hamouda, A.M. 2017. Experimental study of corrugated metal-composite tubes under axial loading. Procedia Engineering, 173, 1314-1321.

20 Khan, Z.R.M. \& Srivastava, S.K. 2018. Development, characterization and application potential of bio-composites: A review. IOP Conference Series: Materials Science and Engineering, 404, 012028.

21 Sebaey, T.A. 2019. Design of oil and gas composite pipes for energy production. Energy Procedia, 162, 146-155.

22 Ighalo, J.O., Adeyanju, C.A., Ogunniyi, S., Adeniyi, A.G., Abdulkareem, S.A. 2020. An empirical review of the recent advances in treatment of natural fibers for reinforced plastic composites. Composite Interfaces, 1-36.

23 Li, S., Guo, X., Li, Q., Ruan, D., \& Sun, G. 2020. On lateral compression of circular aluminum, cfrp and gfrp tubes. Composite Structures, 232, 111534.

24 Suresh, G., Srinivasan, T., Meganathan, S., Ramu, P., Ravi, R., Sai Krishnan, G., \& Vivek, S. 2020. Experimental analysis of compressive behavior of e-glass fiber 
reinforced ipn (vinyl ester/polyurethane) composite pipes. IOP Conference Series: Materials Science and Engineering, 988, 012011.

25 Akkus, N., \& Kawahara, M. 2000. Bending behaviors of thin composite pipes with reinforcing nodes. Materials Science Research International, 6 (2), 131-135.

26 Graupner, N. \& Müssig, J. 2010. Technical applications of natural fibres: An overview. Industrial applications of natural fibres: structure, properties and technical applications, 1, 73-86.

27 Sadat, A. dan Chakraborty, K. 2015. Jute-a biological eixir with multifaceted applications: An overview. International Journal of Research in Pharmaceutical Sciences, 6 (4), 323-332.

28 Sayem, A.S.M., Haider, J., \& Sayeed, M.A. 2020. Development and characterisation of multi-layered jute fabric-reinforced hdpe composites. Journal of Composite Materials, 54 (14), 1831-1845.

29 Sápi, Z. \& Butler, R. 2020. Properties of cryogenic and low temperature composite materials - a review. Cryogenics, 111, 103190.

30 Vinod, B. \& Sudev, L.J. 2019. Study on influence of curing temperature on tensile properties of jute and hemp reinforced hybrid polymer composites. Journal of Physics: Conference Series, 1240, 012029.

31 Vinod, B. \& Sudev, L.J. 2019. Investigation on effect of cryogenic temperature on mechanical behavior of jute and hemp fibers reinforced polymer composites. Applied Mechanics and Materials, 895, 76 - 82.

32 Asim, M., Paridah, M.T., Chandrasekar, M., Shahroze, R.M., Jawaid, M., Nasir, M., \& Siakeng, R. 2020. Thermal stability of natural fibers and their polymer composites. Iranian Polymer Journal, 29 (7), 625-648.

33 Jirawattanasomkul, T., Likitlersuang, S., Wuttiwannasak, N., Ueda, T., Zhang, D., \& Voravutvityaruk, T., 2020. Effects of heat treatment on mechanical properties of jute fiber-reinforced polymer composites for concrete confinement. Journal of Materials in Civil Engineering, 32 (12), 04020363.

34 Zakriya, G.M. \& Ramakrishnan, G. 2019. Jute and hollow conjugated polyester composites for outdoor \& indoor insulation applications. Journal of Natural Fibers, 16 (2), 185-198.

35 Leblanc, J., 2019. Response of composite materials to dynamic and low temperature environments.

36 Firouzsalari, E., Dizhur, S., Jayaraman, D.K., Chouw, N., \& Ingham, J.M. 2020. Flax fabric-reinforced epoxy pipes subjected to lateral compression. Composite Structures, 244, 112307. 